Article

\title{
A Biogeochemical Examination of Ontario's Boreal Forest Ecosite Classification System
}

\author{
Aaron Tamminga ${ }^{1, *}$, Neal A. Scott ${ }^{2}$, Paul Treitz ${ }^{2}$ and Murray Woods ${ }^{3}$ \\ 1 Department of Geography, University of British Columbia, Vancouver, BC V6T 1Z2, Canada \\ 2 Department of Geography, Queen's University, Kingston, ON K7L 3N6, Canada; \\ E-Mails: neal.scott@queensu.ca (N.A.S.); paul.treitz@queensu.ca (P.T.) \\ 3 Ontario Ministry of Natural Resources, North Bay, ON P1A 4L7, Canada; \\ E-Mail: murray.woods@ontario.ca
}

* Author to whom correspondence should be addressed; E-Mail: aarontamminga@gmail.com; Tel.: +1- 604-366-4681; Fax: +1-604-822-6105.

Received: 31 December 2013; in revised form: 13 February 2014 / Accepted: 18 February 2014 / Published: 21 February 2014

\begin{abstract}
The ecosite unit in Ontario's boreal forest ecological land classification system is a polygon of common vegetation type and soil conditions intended to provide a standardized provincial framework to inform meso-scale forestry and planning applications. To determine whether the physical factors used for ecosite classification relate to patterns in ecological function over finer spatial scales, we examined 14 soil properties in replicate boreal forest plots representing eight mineral soil ecosite classes and three organic soil ecosite classes in the Hearst Forest. Despite large differences in vegetation composition, we found few statistically significant differences in properties when compared for individual classes or for more general groupings based on vegetation type and soil texture or expected fertility status. However, some properties (soil organic carbon, total nitrogen, and $\mathrm{C}: \mathrm{N}$ ratio) were approaching significance in the $0-10 \mathrm{~cm}$ depth increment, and there were distinct differences between organic soil and mineral soil sites. Overall, these results suggest few explicit links between ecosystem function and ecosite class at this scale of measurement, highlighting the potential importance of non-steady-state relationships between vegetation species and soil properties in disturbed forests and the potential need for finer-scale characterization to capture patterns in ecosystem function.
\end{abstract}


Keywords: ecological land classification; forest soil classification; boreal forest; ecosite; forest management units; meso-scale forestry

\section{Introduction}

Sustainable forest management requires scientifically informed planning to balance multiple, and often competing, environmental, social, and economic factors. Fundamental to the stewardship of forest systems is a thorough understanding of the spatial patterns of ecosystem structure and function within management units. One tool that is often used for this purpose is ecological land classification (ELC). ELC systems are hierarchical frameworks that subdivide regional landscapes of common climate, geology, and vegetation into increasingly smaller, homogenous units based on the interrelationships between features such as physiography, soils, and vegetation [1]. Many regional permutations of ELC exist, yet most share a common goal of providing a way to spatially interpret the biosphere as subsidiary ecosystems consisting of interacting soils, biota, landforms, and climate [2]. The hierarchical nature of these systems provides a tool that is adaptable and appropriate to the variety of information requirements at various scales needed by environmental planners and resource managers [3].

In Ontario, Canada's National Ecological Framework [4] is codified at a provincial scale through the units of ecozones, ecoregions, and ecodistricts. This system serves as a basis for the province's adaptive approach to land management, consistent with Canadian ecologist Crawford Stanley Holling's groundbreaking research on adaptive management conducted during the 1970s [5]. Originally based on Angus Hills' Site Regions and Districts [6,7], this ELC has a rich history of ongoing refinement in response to new technologies and statistical methods [8], and has been influential in the development of other classification systems internationally (e.g., [3]). At fine spatial scales $(1: 8000$ to $1: 50,000)$, the system is extended through the use of the ecosite unit, which is defined as a landscape area consisting of typical, recurring associations of vegetation and substrate types [9]. The creation of a unit at this scale is part of recent revisions to the ELC system in an attempt to attain a more consistent, province-wide categorical approach to ecosystem classification. With their site-level focus, ecosites are intended to contribute to a flexible standardized framework for meso-scale applications such as forest inventory, natural heritage planning, and interpretation of ecological patterns [10].

To determine ecosites, homogeneous forest polygons are classified based on stable features such as substrate depth, soil texture, and landform [9]. These features are considered the ecological drivers that influence vegetation community structure and function; once they have been identified, the ecosite boundaries are delineated to reflect current vegetation character. The process is achieved through a combination of expert knowledge of plant communities and substrates, ground-based validation of these factors, and remotely sensed data [9].

Once a site has been classified, site quality can be described in terms of the ecological drivers associated with each ecosite class. Figure 1 presents a conceptual edatopic grid for boreal forest mineral soil ecosite classes, adapted to highlight the classes examined in this study. This grid shows 
expected relations among different ecosites - sites can be grouped into general areas (delineated on Figure 1 by dashed lines) based on fertility (as inferred through vegetation species' nutrient requirements and indicator species), soil texture, and moisture levels. The placements of ecosites in this figure can be considered qualitative guidelines for expected site quality, demonstrating the wide range of ecological conditions encompassed by the classification system.

Figure 1. Edatope grid for boreal forest mineral soil ecosites. Ecosite classes sampled in this study are shown in bold; corresponding general groups of texture, moisture, and fertility are shown by grey backgrounds. See Table 1 for descriptions of individual ecosite classes.

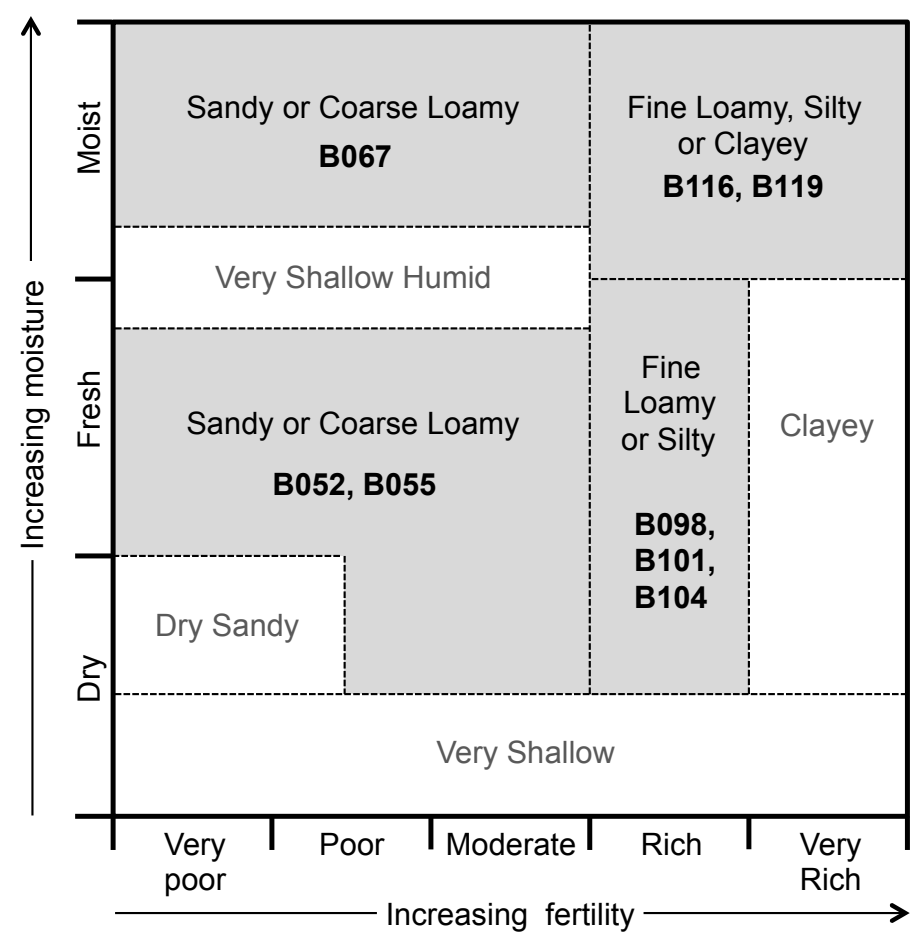

Table 1. Ecosite classes and descriptions.

\begin{tabular}{ccc}
\hline Ecosite class & Description & Number of sites \\
\hline B052 & Dry to fresh, coarse, spruce-fir conifer & 3 \\
B055 & Dry to fresh, coarse, aspen-birch hardwood & 3 \\
B067 & Moist, coarse, spruce-fir conifer & 3 \\
B098 & Fresh, silty to fine loamy, black spruce jack pine dominated & 3 \\
B101 & Fresh, silty to fine loamy, spruce-fir conifer & 3 \\
B104 & Fresh, silty to fine loamy, aspen-birch hardwood & 3 \\
B116 & Moist, fine, spruce-fir conifer & 3 \\
B119 & Moist, fine, aspen-birch hardwood & 3 \\
B127 & Organic poor conifer swamp & 2 \\
B128 & Organic intermediate conifer swamp & 2 \\
B129 & Organic rich conifer swamp & 2 \\
\hline
\end{tabular}


However, while classification based on these main factors is sufficient for most of the intended uses of the classification system, the relationships between these ecological drivers and more dynamic properties such as nutrient and energy cycling that characterize ecosystem function are not explicitly addressed. Similarly, the amount of potential overlap between individual ecosites in terms of moisture and fertility ranges renders quantitative comparisons difficult. Although functional differences may be expected based on the different combinations of moisture level, fertility, and soil texture described by the edatopic grid (e.g., [11]), further study is needed to test whether expected relationships hold true at this general ecosite level of stratification, and whether they influence ecosystem function such as net primary productivity (NPP). As full ecosystem studies in an ELC context that address factors such as disturbance regimes, carbon (C), and nutrient dynamics are a necessary part of adaptive long-term forest management and should be a primary objective of ELC [12], an evaluation of the extent to which ecosystem function is captured by classification of the ecological drivers is required before the full capability of the current ELC system can be determined.

While the ecosite framework is mainly based on differences in more stable features largely related to soil properties, it is also clear that in many cases individual ecosite classes contain unique mixes of plant species. Previous work has suggested several mechanisms by which tree species might alter ecosystem function - many of these are summarized in Binkley and Giardina [13]. For example, differences in litter quality may influence net nitrogen $(\mathrm{N})$ mineralization associated with different species at the same site [14], and across broad climate gradients [15]. These species effects represent an important feedback mechanism in terrestrial ecosystems and can modify soil $\mathrm{N}$ dynamics quickly relative to soil development rates [16]. Changes in species composition may also alter soil $\mathrm{C}$ stocks [17] or forest floor mass [14]. Variations in tree species characteristics have also been shown to influence soil microbial community structure [18]. Based on this previous work, we would expect that ecosite classes dominated by different plant communities would differ in some of these ecosystem functional attributes.

The objective of this work was to explore the relationships between ecosite class and a wide range of factors related to ecosystem function in boreal forest stands as defined by Ontario's boreal forest ecosite classification system. We sampled soils to $40 \mathrm{~cm}$ depth in replicate ecosites in an operationally managed boreal forest located in Hearst, $\mathrm{ON}$ and used ecosite class averages to compare properties between different classes. In particular, we focused on soil $\mathrm{N}$ and $\mathrm{C}$ dynamics, along with closely related factors likely to be impacted by the combination of ecological drivers and plant community type. If the ecosite unit can be used to represent functional patterns without further intensive sampling beyond that already used for classification, it has the potential to effectively contribute to detailed spatial ecological models that can inform a wide range of applications such as forest harvest and regeneration planning, regional $\mathrm{C}$ inventories, and acid deposition susceptibility assessment. More generally, reliable ecosystem unit data could be useful during impact assessments prior to land development or development of recreational opportunities. 


\section{Experimental Section}

\subsection{Site Description}

This study was conducted at the Hearst Forest, Ontario (Figure 2), which consists of approximately $1,525,000$ ha surrounding the town of Hearst $\left(49^{\circ} 40^{\prime} \mathrm{N}, 83^{\circ} 40^{\prime} \mathrm{W}\right)$. The climate of the area is classified as modified continental with strong continental temperature extremes combined with the modifying influence and added moisture of the Great Lakes and the Hudson Bay [19]. The area exhibits little topographic relief due to the combination of several glaciations and lacustrine deposits from glacial lake Barlow-Ojibway (10.1-8.0 ka BP). In some areas, however, exposed pre-Cambrian bedrock contributes to a topography that varies from gently rolling to very hilly. Soils generally fall into two main categories: the Great Clay Belt in the north and central portions (glacial-lacustrine sediments and soils consisting of clays through silt clays to clay loams), and more varied clays, loams, and sands in the southern, southwest, and northeast portions of the forest [19]. There are also areas of poorly drained, low-lying organic soils interspersed throughout the forest, particularly in the Great Clay Belt region.

Figure 2. Map of sampling locations within Hearst Forest and of Hearst Forest's location within Ontario (inset).

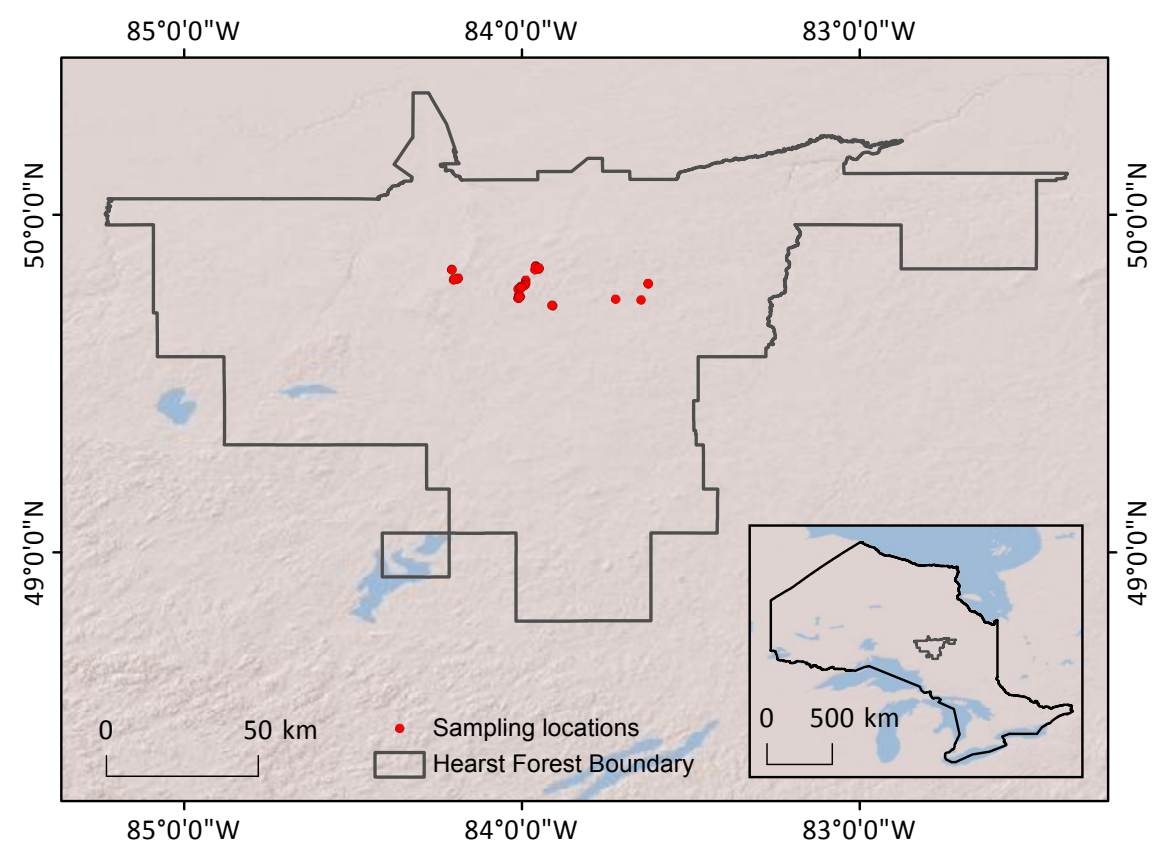

The vegetation is typical of the northeastern boreal forest, with black spruce (Picea mariana [Mill.] BSP) as the dominant species. In lowland areas with organic soils, black spruce is often found in association with northern white cedar (Thuja occidentalis L.) and eastern larch (Larix laricina [Du Roi] K. Koch). Black spruce is also found in better-drained upland sites, where it often grows in association with white spruce (Picea glauca [Moench] Voss), jack pine (Pinus banksiana Lamb.), balsam fir (Abies balsamea [L.] Mill.), and trembling aspen (Populus tremuloides Michx.). Other important tree species include balsam poplar (Populus balsamifera L.) and white birch (Betula papyrifera Marsh.), which typically grow on upland mineral soils [19]. Many of these species 
are valued as sources of merchantable timber; the forest is managed under a 20-year Sustainable Forest License administered by the Ontario Ministry of Natural Resources (OMNR) with Hearst Forest Management Inc. (HFMI) as the license holder. Several independent logging firms operate under HFMI guidance, providing both conifer and hardwood timber to local mills and manufacturing operations.

The current forest characteristics reflect the influence of commercial harvest as well as widespread fire suppression that started in the 1920s. Prior to fire suppression, natural wildfires gave rise to a patchy mosaic of different age class stands, and an estimated 120 to 140 year return interval of fires kept the forest younger than it is today [19]. As a result of low harvest levels until the 1940s, 39 percent of the current forest is classified as over-mature and older than 100 years, but current management plans focus on emulating previous natural disturbance patterns through harvest rates that keep the forest age classes younger overall [19].

\subsection{Sample Collection and Preparation}

To evaluate differences in biogeochemical characteristics among ecosite classes throughout the forest, we used pre-existing forest inventory plots that had been established earlier in summer of 2010 as part of a larger GEOIDE-funded project titled Precision Planning Inventory Tools for Forest Value Enhancement. As part of this project, circular $400 \mathrm{~m}^{2}$ forest inventory plots representing different vegetation-soil combinations were identified and assigned an ecosite class according to the OMNR ecosite classification guide. Working with established sites, we used stratified random sampling to select three (when possible) replicate sites for 11 ecosite classes commonly found in the Hearst Forest (Table 1). Although the ecosite classification procedure does include some characterization of finer-scale environmental variability (e.g., specific soil groups or tree growth stages), we were interested only in differences at the overall ecosite level and chose our replicates accordingly. Select ground-level photos representing example sites of different ecosite classes are shown in Figure 3.

The ecosite classes selected included mineral soil sites (ecosites B052, B055, B067, B098, B101, B104, B116 and B119) and saturated organic soil sites (ecosites B127, B128 and B129). Soil sampling procedures differed slightly between the two site types due to fundamental substrate differences. At each mineral soil site, we established an $11 \mathrm{~m}$ transect running north-south through the plot center, and sampled the $\mathrm{O}$ horizon material at each endpoint inside a $20 \mathrm{~cm}$ diameter ring, noting depth to mineral soil. The two $\mathrm{O}$ horizon samples were then mixed and bulked as a composite sample. With the $\mathrm{O}$ horizon material removed, we sampled the mineral soil in the same spots to $40 \mathrm{~cm}$ depth using a $5.6 \mathrm{~cm}$ diameter soil corer (Giddings Machine Corporation, Fort Collins, CO, USA). The cores were partitioned into depth increments of $0-10 \mathrm{~cm}, 10-20 \mathrm{~cm}$, and $20-40 \mathrm{~cm}$, and increments from both cores were bulked as composite samples. Soil samples were kept on ice in coolers during travel and then refrigerated at $5{ }^{\circ} \mathrm{C}$ until analysis at the Facility for Biogeochemical Research on Environmental Change and the Cryosphere (FABRECC) laboratory at Queen's University.

At sites characterized as organic soils, composite samples were also created from cores at each end of an $11 \mathrm{~m}$ north-south transect. However, because sample compaction in the corer prohibited the delineation of even depth increments, the soil cores were partitioned into surface and subsurface increments based on visible differences in the degree of decay of the organic material. Cores were 
taken to $40 \mathrm{~cm}$ depth (once overlying live sphagnum moss was removed), with depth values based on hole depths (not core length) to account for compaction of the organic material during coring. All samples for both mineral and organic sites were collected between 22-25 August 2010.

Figure 3. Examples of stands representing different ecosite classes. (a) B098: Fresh, silty to fine loamy, black spruce jack pine dominated; (b) B101: Fresh, silty to fine loamy, spruce-fir conifer; (c) B104: Fresh, silty to fine loamy, aspen-birch hardwood; (d) B128: Organic intermediate conifer swamp.
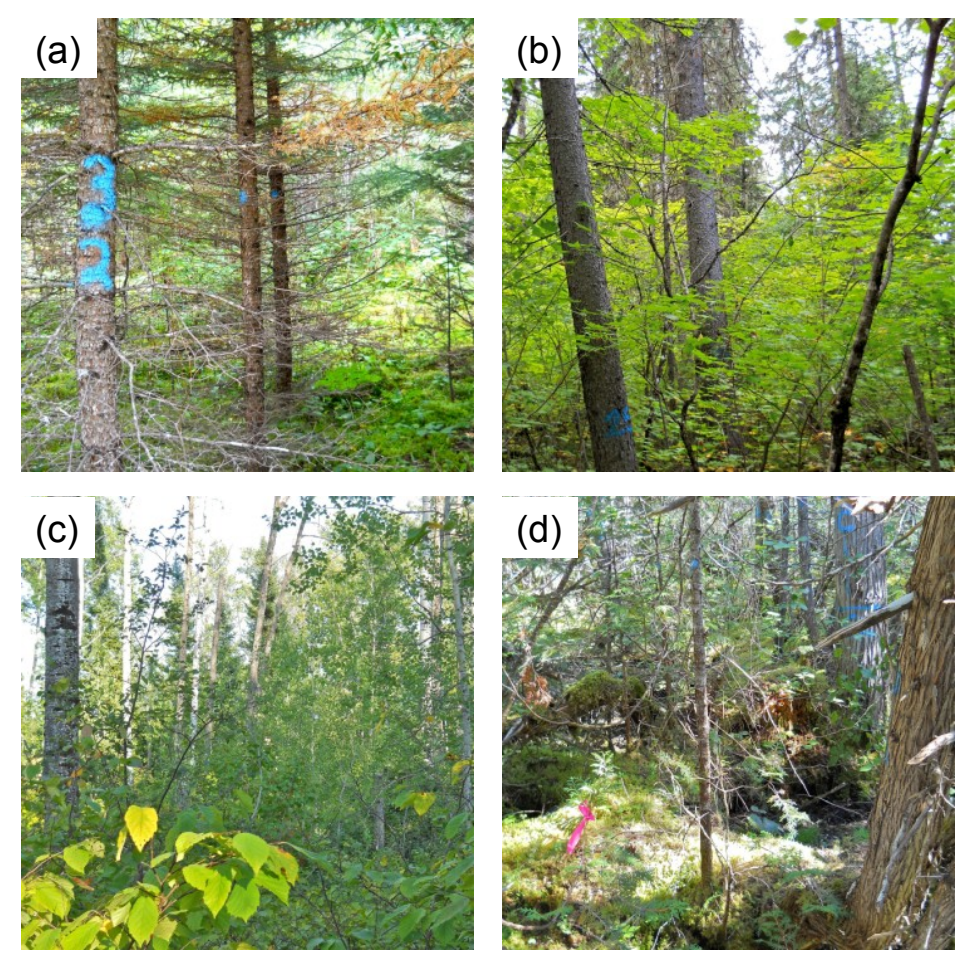

To measure in situ available nutrient pools in the soil solution, we inserted resin strips at each site. These $10 \times 2 \mathrm{~cm}$ strips are electrostatically charged membranes designed to quantify available nutrient pools by absorbing cations and anions from the soil solution [20]. The strips were cut from large ion-exchange resin membrane sheets typically used in the wastewater industry (GE Water, Trevose, PA, USA) and inserted vertically into slits cut into the top $10 \mathrm{~cm}$ of mineral soil (or the surface organic soil for organic sites). At each plot, we inserted two sets of anion and cation resin strips $3 \mathrm{~m}$ from the plot center each direction along the transect. The resin strips were left in the soil for two months (22-25 August through 24-25 October) to capture late-season differences in available nutrient pools. At the end of this period they were removed from the soil, rinsed with de-ionized water to remove large soil particles, and kept refrigerated until laboratory extraction. A set of two unused anion resin strips and two cation resin strips were rinsed in the same fashion and treated as controls. Upon collection, it was discovered that some strips were disturbed and showed signs of animal bites or were missing completely; only undisturbed strips were used for subsequent analysis.

In the lab, we sieved the mineral soil through a $2 \mathrm{~mm}$ sieve to separate out rocks and roots. $\mathrm{O}$ horizon samples from mineral sites and soils from organic sites were passed through a $5.6 \mathrm{~mm}$ sieve to homogenize the sample and remove coarse woody debris (which was designated as wood pieces larger 
than $1 \mathrm{~cm}$ in diameter). Roots and rocks were then rinsed, dried at $65^{\circ} \mathrm{C}$ for $24 \mathrm{~h}$ and weighed. A small subsample $(8-10 \mathrm{~g})$ from each soil sample was dried at $105{ }^{\circ} \mathrm{C}$ for $24 \mathrm{~h}$ to determine the percent moisture, which was used to calculate the total soil dry weight and fine earth bulk density based on the volume of the corer minus the volume of the roots and rocks. All subsequent analyses were performed on $<2 \mathrm{~mm}$ sieved soil.

Soil $\mathrm{pH}$ was determined by combining $10 \mathrm{~g}$ of soil with $10 \mathrm{~mL}$ of de-ionized water, shaking on an automatic shaker table for $5 \mathrm{~min}$, then measuring the $\mathrm{pH}$ of the mixture with a benchtop Oakton $\mathrm{pH}$ meter (Oakton Instruments, Vernon Hills, IL, USA).

To determine water-holding capacity (WHC) of the soils (0-10 cm mineral samples and subsurface organic samples only), we placed $25 \mathrm{~g}$ of soil (10 g for organic samples) and $25 \mathrm{~mL}$ (10 mL for organic samples) of water into funnels with a small piece of aquarium fiber in the bottom. The neck of the funnel was sealed with a rubber stopper. We covered the funnels with plastic-wrap to prevent evaporation, and let them sit for $24 \mathrm{~h}$, after which we removed the stoppers and allowed the water to drain for six hours. We then weighed the samples, dried them at $105{ }^{\circ} \mathrm{C}$ overnight, and reweighed them to determine the moisture content associated with $100 \% \mathrm{WHC}$ for each soil.

We determined organic matter (OM) content using the loss-on-ignition (LOI) method [21]. We first weighed empty pre-ashed ceramic crucibles to an accuracy of $0.1 \mathrm{mg}$, added $3 \mathrm{~g}$ of field-moist soil to the beakers, and placed the samples into an oven at $105^{\circ} \mathrm{C}$ for $24 \mathrm{~h}$. After $24 \mathrm{~h}$, we cooled the samples in a dessicator and reweighed them, and then combusted them in a muffle furnace at $400{ }^{\circ} \mathrm{C}$ for $16 \mathrm{~h}$. The samples were then cooled in the dessicator and reweighed. To calculate the percent LOI (assumed to equal the percent $\mathrm{OM}$ ), we used the equation:

$$
\% L O I=100\left[\frac{\text { eeight }_{105}-\text { weight }_{400}}{\text { weight }_{105}}\right]
$$

where weight ${ }_{105}$ denotes the weight after oven drying at $105^{\circ} \mathrm{C}$ and weight ${ }_{400}$ denotes the weight after ignition at $400{ }^{\circ} \mathrm{C}$.

Following ignition at $400{ }^{\circ} \mathrm{C}$, the soils were returned to the muffle furnace at $950{ }^{\circ} \mathrm{C}$ for $2 \mathrm{~h}$ to evolve all carbon dioxide $\left(\mathrm{CO}_{2}\right)$ from any carbonate materials. The mass loss during this stage can be used to determine percent carbonate as described by Rayment and Lyons [22]. After ignition, the samples were cooled in a dessicator and reweighed. Percent $\mathrm{LOI}_{950}$ was calculated with the equation:

$$
\%{ }^{2} O I_{950}=100\left[\frac{\text { weight }_{400}-\text { weight }_{950}}{\text { weight }_{105}}\right]
$$

where weight 400 denotes the weight after ignition at $400{ }^{\circ} \mathrm{C}$, weight ${ }_{950}$ denotes the weight after ignition at $950{ }^{\circ} \mathrm{C}$, and weight ${ }_{105}$ denotes the weight after oven drying at $105^{\circ} \mathrm{C}$. Percent carbonate is assumed to approximate the percent $\mathrm{LOI}_{950}$ multiplied by 1.36 , which is the ratio of the mass of carbonate $\left(\mathrm{CO}_{3}{ }^{2-}=60 \mathrm{~g} / \mathrm{mol}\right)$ divided by the mass of $\mathrm{CO}_{2}(44 \mathrm{~g} / \mathrm{mol})$.

To extract ammonium $\left(\mathrm{NH}_{4}{ }^{+}\right)$and nitrate $\left(\mathrm{NO}_{3}{ }^{-}\right)$from the soils, we first weighed out $10 \mathrm{~g}$ of soil ( $3 \mathrm{~g}$ for organic samples) into specimen cups and added $75.0 \mathrm{~mL}$ of $2 \mathrm{~N}$ potassium chloride $(\mathrm{KCl})$. We put the cups on an automatic shaker table for $45 \mathrm{~min}$ and then filtered samples into plastic scintillation vials using Fisherbrand Q5 filter paper. The filtrates were kept frozen until analyzed colorimetrically 
on an Astoria2 Analyzer (Astoria Pacific International, Clackamas, OR, USA) by cadmium reduction (for $\mathrm{NO}_{3}{ }^{-}$) and a phenolate method (for $\mathrm{NH}_{4}{ }^{+}$) $[23,24]$.

Resin strip extraction was performed according to a procedure developed in May 2010 that was shown to result in $\sim 90 \%$ recovery of ions from loaded strips. Strips were extracted with $0.5 \mathrm{~N}$ hydrochloric acid $(\mathrm{HCl})$ to cause the soil solution ions that had bound to the strips while they were in the field to be displaced by $\mathrm{H}^{+}$and $\mathrm{Cl}^{-}$ions. First, each strip was rinsed with de-ionized water to remove any remaining soil particles. The strips were then placed in $100 \mathrm{~mL}$ of $0.5 \mathrm{~N} \mathrm{HCl}$ and shaken on an automatic shaker table for $30 \mathrm{~min}$. Both cations strips and both anion strips from each plot were extracted together, yielding one composite anion sample and one composite cation sample for each plot. After shaking, the strips were removed from the acid, rinsed again with de-ionized water, air dried, and weighed. The ion-containing $\mathrm{HCl}$ for the anion samples was then neutralized to between pH 5 and pH 9 with $5 \mathrm{~N}$ sodium hydroxide $(\mathrm{NaOH})$, while the cation extracts were left acidified; these steps were taken so the samples conformed with $\mathrm{pH}$ requirements for subsequent colorimetric analysis. Both extract types were then analyzed using the same method as the $\mathrm{KCl}$ extractions to determine the amount of $\mathrm{NO}_{3}{ }^{-}-\mathrm{N}$ and $\mathrm{NH}_{4}{ }^{+}-\mathrm{N}$ in the extracts. The control anion and cation strips were treated in the same manner. We expressed $\mathrm{NO}_{3}{ }^{-}-\mathrm{N}$ and $\mathrm{NH}_{4}{ }^{+}-\mathrm{N}$ values per dry weight of resin strip.

To determine soil organic $\mathrm{C}$ (SOC) and total N, samples were air-dried and then ground using a ball mill (SPEX Certiprep 8000M, Metuchen, NJ, USA). A $0.3 \mathrm{~g}$ sample was then weighed into aluminum foil, wrapped, and analyzed by thermal combustion using a LECO Truspec CN (LECO Corporation, St. Joseph, MI, USA). Values were corrected for residual water content using the percent moisture of air-dried soil determined by the $105^{\circ} \mathrm{C}$ oven drying stage in the LOI procedure. As some samples were from areas with soils classified as calcareous, the amount of $\mathrm{C}$ contained in carbonate (determined by multiplying percent carbonate as measured by $\mathrm{LOI}_{950}$ by 0.20014 to account for $\mathrm{C}=12 \mathrm{~g} / \mathrm{mol}$ and $\mathrm{CO}_{3}{ }^{2-}=60 \mathrm{~g} / \mathrm{mol}$ ) was subtracted from the total soil $\mathrm{C}$, yielding $\mathrm{SOC}$.

Aboveground $\mathrm{C}$ data for each plot were provided by the OMNR, who performed a detailed inventory of tree species and diameter at breast height for each plot throughout the summer of 2010. Aboveground biomass $(\mathrm{Mg} / \mathrm{ha})$ had been calculated for each site using allometric relationships summarized in Ter-Mikaelian and Korzukhin [25], and we used a factor of 0.50 to convert biomass values to $\mathrm{C}$. Aboveground $\mathrm{C}$ and SOC values were also added together as a measure of total organic $\mathrm{C}$ at each site.

To determine microbial respiration rates and $\mathrm{N}$ mineralization during laboratory incubations, $20 \mathrm{~g}$ of soil ( $5 \mathrm{~g}$ for organic soils) were brought up to $60 \% \mathrm{WHC}$ to provide a standardized moisture level optimal for microbial activity. We then incubated the soils for 7 days at $21{ }^{\circ} \mathrm{C}$ along with a vial of $3.5 \mathrm{~mL}$ of $0.5 \mathrm{~N} \mathrm{NaOH}$ in tightly sealed $1 \mathrm{~L}$ mason jars. The $\mathrm{NaOH}$ absorbed $\mathrm{CO}_{2}$ produced by microbial respiration throughout the incubation period. At the end of the incubation, we removed a $1 \mathrm{~mL}$ aliquot of the $\mathrm{NaOH}$, added $0.5 \mathrm{~mL}$ of $0.75 \mathrm{~N}$ barium chloride $\left(\mathrm{BaCl}_{2}\right)$ and 2 drops of phenolphthalein indicator, and titrated with $0.5 \mathrm{~N} \mathrm{HCl}$ with a Gilson microburette (Gilson Corp., Middleton, WI, USA) to determine how much $\mathrm{CO}_{2}$ had been produced. Values were corrected based on $\mathrm{CO}_{2}$ absorbed by a blank $\mathrm{NaOH}$ trap over the same time period, and $\mathrm{CO}_{2}$ production rate was expressed per gram of dry soil as well as per gram of soil $\mathrm{C}$. We also performed pre- and post-incubation $\mathrm{KCl}$ extractions as previously described to determine net $\mathrm{N}$ mineralization (net $\mathrm{N}_{\text {min }}$ ) during the incubation period. 


\subsection{Statistical Analysis}

Differences between ecosite class averages for all factors were assessed using $\mathrm{R}$ version 2.13.1 [26]. Due to the different substrate compositions and the lack of comparable depth increments between organic and mineral soil sites, the two groups were analyzed separately. For mineral soil sites, properties were compared for each depth increment separately (Table 2). Surface and subsurface increments for organic sites were combined and all properties were analyzed as whole-profile averages (or totals to $40 \mathrm{~cm}$ depth for factors calculated on an areal basis). Following examination of results, it was determined that deep and heterogeneous OA horizons in four mineral soil sites (representing one replicate each for classes B052, B101, B104 and B119) had resulted in an indeterminate O horizon/mineral soil interface. As a result, the upper mineral soil increments at these sites were misclassified and contained excessive amounts $(>30 \%)$ of organic matter, which changed most soil properties and rendered quantitative comparisons with correctly handled sites unreliable (a common problem in forest soil sampling, [27]). For this reason, these four sites were excluded from statistical analyses.

Data were first tested for normality using the Shapiro-Wilk's test and for homogeneity of variance using Levene's test. If a variable was not normally distributed, four potential transformations were applied in this order: square root, natural $\log , \log$, and inverse. If values of less than one were present prior to transformation, a constant value of one was added to ensure consistent transformation effects. Following transformations, variables that met parametric assumptions were tested using one-way analysis of variance with $p<0.05$ as the cut-off for significant effects. If significant differences were found, between-ecosite class differences were determined using Tukey's HSD test $(p<0.05)$. Variables that did not meet the assumptions (even with transformations) for parametric testing were analyzed using the Kruskal-Wallis test $(p<0.05)$ based on median ranks.

Following individual ecosite class analysis, mineral soil ecosite clusters made up of several ecosite classes were created based on broad vegetation and soil texture characteristics (Table 3). Amalgamating ecosite types allowed for easier examination of vegetation-soil relationships at a more general level of the ecosite classification framework, and created groups with better replication for more robust statistical comparisons. Clusters were based on two factors: soil texture (coarse or fine) and vegetation type (deciduous or coniferous), yielding four mineral soil combinations. For a general evaluation of differences between organic and mineral soil sites and to assess the ecosite framework's applicability to $\mathrm{C}$ inventories a fifth cluster (organic) was added and SOC, aboveground $\mathrm{C}$, and total C were then compared for all clusters. In this case, total SOC to $40 \mathrm{~cm}$ depth was used to make comparisons between mineral and organic sites valid. Statistical differences between ecosite clusters were determined in the same manner as individual ecosite classes.

For a direct comparison with the edatope grid (Figure 1), mineral soil ecosites were also divided by fertility status into two groups: poor (ecosites B052, B055, and B067) and rich (ecosites B098, B101, B104, B116, and B119). The poor class included ecosites ranging from very poor to moderate fertility on Figure 1, while the rich class included the rich and very rich rankings. Extractable $\mathrm{N}$ (sum of $\mathrm{NH}_{4}{ }^{+}-\mathrm{N}$ and $\mathrm{NO}_{3}{ }^{-}-\mathrm{N}$ ) and total $\mathrm{N}$ were chosen as properties directly related to fertility and compared between the two classes using $\mathrm{t}$ tests $(p<0.05)$ or Wilcoxon rank sum tests $(p<0.05)$ for nonparametric variables. 
Table 2. Ecosite class averages (standard errors) by depth.

\begin{tabular}{|c|c|c|c|c|c|c|c|c|c|c|}
\hline Property & Depth & $p$ value & B052 & B055 & B067 & B098 & B101 & B104 & B116 & B119 \\
\hline \multirow[t]{4}{*}{ Moisture (\%) } & O horiz & 0.016 & $155.8(62.7) \mathrm{ab}$ & $71.2(12.2) \mathrm{a}$ & $90.2(21.6) \mathrm{a}$ & $85.6(2.7) \mathrm{a}$ & $113.1(15.7) \mathrm{ab}$ & $94.4(15.4) \mathrm{ab}$ & $256.7(48.2) \mathrm{b}$ & $188.8(55.5) \mathrm{ab}$ \\
\hline & $0-10$ & 0.49 & $26.57(0.87)$ & $31.44(4.56)$ & $26.84(1.43)$ & $30.18(1.19)$ & $33.76(6.27)$ & $29.33(1.73)$ & $46.14(19.08)$ & $54.54(12.30)$ \\
\hline & $10-20$ & 0.85 & $18.63(2.55)$ & $22.17(3.01)$ & $19.73(0.80)$ & $20.17(1.17)$ & $20.68(4.29)$ & $23.35(1.82)$ & $20.45(3.45)$ & $23.96(1.59)$ \\
\hline & $20-40$ & 0.78 & $18.42(4.00)$ & $18.94(1.32)$ & $18.35(1.86)$ & $22.18(1.50)$ & $18.35(2.46)$ & $18.27(2.39)$ & $20.03(1.23)$ & $18.71(1.21)$ \\
\hline \multirow{4}{*}{$\begin{array}{c}\text { Bulk density } \\
\left(\mathrm{g} / \mathrm{cm}^{3}\right)\end{array}$} & O horiz & 0.12 & $0.29(0.17)$ & $0.70(0.21)$ & $0.17(0.03)$ & $0.19(0.02)$ & $0.19(0.06)$ & $0.24(0.05)$ & $0.18(0.07)$ & $0.25(0.07)$ \\
\hline & $0-10$ & 0.87 & $0.88(0.00)$ & $0.89(0.05)$ & $0.85(0.05)$ & $0.82(0.09)$ & $0.67(0.09)$ & $0.89(0.01)$ & $0.78(0.23)$ & $0.73(0.03)$ \\
\hline & $10-20$ & 0.27 & $1.19(0.05)$ & $1.11(0.05)$ & $1.25(0.02)$ & $1.41(0.04)$ & $1.08(0.05)$ & $1.09(0.01)$ & $1.23(0.23)$ & $1.45(0.10)$ \\
\hline & $20-40$ & 0.71 & $1.34(0.21)$ & $1.42(0.12)$ & $1.41(0.05)$ & $1.43(0.04)$ & $1.52(0.06)$ & $1.42(0.01)$ & $1.54(0.11)$ & $1.62(0.03)$ \\
\hline \multirow[t]{4}{*}{$\mathrm{pH}$} & O horiz & 0.67 & $5.76(0.86)$ & $6.78(0.14)$ & $6.25(0.05)$ & $6.39(0.20)$ & $6.38(0.40)$ & $6.44(0.07)$ & $5.96(0.53)$ & $5.82(0.66)$ \\
\hline & $0-10$ & 0.98 & $5.66(0.41)$ & $6.40(0.48)$ & $6.21(0.39)$ & $6.19(0.20)$ & $6.02(0.33)$ & $5.95(1.11)$ & $6.05(0.49)$ & $5.93(0.00)$ \\
\hline & $10-20$ & 0.51 & $5.54(0.15)$ & $5.26(0.21)$ & $5.70(0.63)$ & $5.98(0.17)$ & $6.47(0.05)$ & $5.93(0.79)$ & $6.15(0.36)$ & $6.20(0.08)$ \\
\hline & $20-40$ & 0.18 & $6.14(0.71)$ & $5.64(0.31)$ & $4.96(0.77)$ & $6.35(0.40)$ & $7.29(0.18)$ & $5.1(0.24)$ & $6.74(0.13)$ & $7.71(0.13)$ \\
\hline \multirow[t]{4}{*}{ OM (\%) } & O horiz & 0.41 & $61.96(17.41)$ & $53.17(6.28)$ & $79.57(7.89)$ & $54.71(14.71)$ & $57.81(10.33)$ & $63.25(5.47)$ & $74.16(7.31)$ & $78.52(7.15)$ \\
\hline & $0-10$ & 0.28 & $6.18(1.60)$ & $9.01(0.78)$ & $5.87(1.06)$ & $8.84(1.10)$ & $12.73(0.28)$ & $7.60(1.86)$ & $12.18(6.11)$ & $17.12(1.05)$ \\
\hline & $10-20$ & 0.44 & $3.04(0.08)$ & $4.64(0.44)$ & $2.99(0.64)$ & $4.06(0.93)$ & $4.42(0.41)$ & $6.04(1.87)$ & $3.57(1.15)$ & $4.43(0.78)$ \\
\hline & $20-40$ & 0.68 & $2.39(0.87)$ & $2.02(0.78)$ & $2.19(0.17)$ & $3.20(0.49)$ & $2.66(0.51)$ & $3.24(0.45)$ & $2.70(0.49)$ & $2.37(0.12)$ \\
\hline \multirow[t]{4}{*}{$\mathrm{SOC}(\mathrm{Mg} / \mathrm{ha})$} & O horiz & 0.59 & $17.59(12.25)$ & $2.96(0.62)$ & $9.92(5.74)$ & $4.32(1.22)$ & $8.46(2.39)$ & $2.94(0.71)$ & $25.91(11.80)$ & $6.63(1.62)$ \\
\hline & $0-10$ & 0.048 & $25.36(10.75) \mathrm{a}$ & $41.38(1.73) \mathrm{ab}$ & $25.21(6.51) \mathrm{a}$ & 36.85 (2.60)ab & $44.86(5.83) \mathrm{ab}$ & $43.95(7.00) \mathrm{ab}$ & 33.96 (11.11)ab & $66.92(7.86) \mathrm{b}$ \\
\hline & $10-20$ & 0.34 & $9.16(3.16)$ & $19.32(1.32)$ & $12.15(4.49)$ & $18.72(7.03)$ & $15.43(1.20)$ & $28.95(11.32)$ & $10.99(4.12)$ & $20.41(4.64)$ \\
\hline & $20-40$ & 0.58 & $12.76(6.48)$ & $12.94(0.90)$ & $11.08(2.57)$ & $12.96(4.59)$ & $12.79(2.49)$ & $24.18(7.25)$ & $12.8(3.87)$ & $10.57(0.54)$ \\
\hline \multirow[t]{4}{*}{ Total N (Mg/ha) } & O horiz & 0.54 & $0.58(0.43)$ & $0.067(0.17)$ & $0.35(0.24)$ & $0.93(0.021)$ & $0.26(0.083)$ & $0.061(0.024)$ & $0.94(0.44)$ & $0.23(0.096)$ \\
\hline & $0-10$ & 0.021 & $1.46(0.46) \mathrm{ab}$ & $2.23(0.21) \mathrm{ab}$ & $1.29(0.31) \mathrm{a}$ & $1.88(0.14) \mathrm{ab}$ & $2.26(0.23) \mathrm{ab}$ & $1.85(0.39) a b$ & $1.45(0.53) \mathrm{ab}$ & $3.61(0.44) b$ \\
\hline & $10-20$ & 0.31 & $0.70(0.05)$ & $1.42(0.19)$ & $0.98(0.37)$ & $1.32(0.34)$ & $1.39(0.09)$ & $1.69(0.52)$ & $0.93(0.20)$ & $1.65(0.05)$ \\
\hline & $20-40$ & 0.18 & $1.53(0.46)$ & $2.05(0.17)$ & $0.99(0.22)$ & $2.22(0.45)$ & $1.70(0.10)$ & $2.21(0.53)$ & $1.92(0.25)$ & $1.70(0.19)$ \\
\hline
\end{tabular}


Table 2. Cont

\begin{tabular}{|c|c|c|c|c|c|c|c|c|c|c|}
\hline Property & Depth & $p$ value & B052 & B055 & B067 & B098 & B101 & B104 & B116 & B119 \\
\hline \multirow[t]{4}{*}{$\mathrm{C}: \mathrm{N}$ ratio } & O horiz & 0.36 & $32.63(2.95)$ & $45.14(2.27)$ & $70.34(39.54)$ & $45.02(6.16)$ & $32.91(1.29)$ & $51.74(9.10)$ & $28.59(2.27)$ & $31.59(6.18)$ \\
\hline & $0-10$ & 0.018 & $16.73(2.14) \mathrm{a}$ & $18.74(1.23) \mathrm{ab}$ & $19.33(0.35) \mathrm{ab}$ & $19.63(0.32) a b$ & $19.82(0.60) a b$ & $17.83(0.04) \mathrm{a}$ & $23.94(1.59) \mathrm{b}$ & $18.54(0.09) \mathrm{ab}$ \\
\hline & $10-20$ & 0.85 & $12.89(3.66)$ & $13.89(1.06)$ & $14.71(4.54)$ & $13.32(1.52)$ & $11.18(1.59)$ & $16.67(1.58)$ & $11.02(1.94)$ & $12.26(2.45)$ \\
\hline & $20-40$ & 0.16 & $7.75(1.88)$ & $6.46(0.89)$ & $11.71(2.91)$ & $5.53(0.86)$ & $7.62(1.92)$ & $10.75(0.67)$ & $6.51(1.31)$ & $6.27(0.40)$ \\
\hline \multirow[t]{3}{*}{$\mathrm{NH}_{4}{ }^{+}-\mathrm{N}(\mathrm{kg} / \mathrm{ha})$} & O horiz & 0.67 & $0.70(0.53)$ & $0.18(0.11)$ & $0.81(0.70)$ & $0.10(0.02)$ & $0.31(0.04)$ & $0.09(0.02)$ & $4.17(3.80)$ & $0.19(0.58)$ \\
\hline & $0-10$ & 0.92 & $1.29(0.70)$ & $3.96(2.91)$ & $3.37(1.95)$ & $3.36(2.15)$ & $1.13(0.30)$ & $0.79(0.16)$ & $2.24(1.22)$ & $1.10(0.19)$ \\
\hline & $10-20$ & 0.54 & $1.33(0.36)$ & $1.95(1.06)$ & $1.07(0.07)$ & $3.91(1.70)$ & $2.45(1.81)$ & $0.84(0.11)$ & $3.70(1.71)$ & $3.25(0.24)$ \\
\hline \multirow[t]{3}{*}{$\mathrm{NO}_{3}^{-}{ }^{-} \mathrm{N}(\mathrm{kg} / \mathrm{ha})$} & O horiz & 0.77 & $0(0)$ & $0.003(0.003)$ & $0.06(0.06)$ & $0(0)$ & $0(0)$ & $0(0)$ & $0.14(0.14)$ & $0(0)$ \\
\hline & $0-10$ & 0.11 & $0.31(0.29)$ & $0.027(0.027)$ & $0.13(0.13)$ & $1.92(1.89)$ & $0.1(0.1)$ & $0(0)$ & $1.33(0.74)$ & $6.44(5.71)$ \\
\hline & $10-20$ & 0.24 & $0.14(0.14)$ & $0.05(0.05)$ & $0.025(0.025)$ & $0.10(0.10)$ & $0.14(0.14)$ & $0(0)$ & $0.82(0.43)$ & $1.94(0.28)$ \\
\hline Resp (ug C/g soil/min) & $0-10$ & 0.97 & $46.61(26.94)$ & $64.57(3.40)$ & $55.65(9.58)$ & $55.31(11.68)$ & $73.34(3.94)$ & $49.96(5.29)$ & $65.13(35.13)$ & $57.32(2.55)$ \\
\hline Resp (ug C/g) soil C/min) & $0-10$ & 0.32 & $1489.0(300.3)$ & $1386.2(33.8)$ & $2011.9(396.6)$ & $1183.7(182.8)$ & $1090.9(49.9)$ & $1448.5(467.7)$ & $1365.3(536.1)$ & $633.9(80.0)$ \\
\hline Resin $\mathrm{NH}_{4}^{+}-\mathrm{N}$ (ug N/g resin) & $0-10$ & 0.83 & $9.95(5.74)$ & $4.29(1.92)$ & 0 (na) & $0.28(\mathrm{na})$ & $7.27(5.12)$ & na (na) & $6.24(2.93)$ & $9.45(9.02)$ \\
\hline Resin $\mathrm{NO}_{3}{ }^{-}-\mathrm{N}$ (ug N/g resin) & $0-10$ & 0.46 & $0.041(0.041)$ & $0.087(0.048)$ & $0.83(0.70)$ & $0.043(0.023)$ & $0.167(0.0025)$ & $0.32(0.32)$ & $0.52(0.41)$ & $0.23(0.040)$ \\
\hline Net $N_{\min }(\mathrm{mg} \mathrm{N} / \mathrm{kg}$ soil/day) & $0-10$ & 0.72 & $4.41(1.36)$ & $0.73(0.58)$ & $3.82(1.35)$ & $4.08(2.03)$ & $3.06(1.89)$ & $4.12(0.65)$ & $5.22(2.48)$ & $3.39(2.26)$ \\
\hline $100 \% \mathrm{WHC}$ & $0-10$ & 0.32 & $68.23(7.76)$ & $81.19(4.29)$ & $62.23(8.60)$ & $74.73(3.61)$ & $95.18(8.00)$ & $74.88(4.95)$ & $86.45(30.82)$ & $120.24(3.45)$ \\
\hline
\end{tabular}

ANOVA $p$ values $<0.05$ are highlighted in bold. Significantly different values (Tukey's test $p<0.05$ ) are denoted by different letters row-wise per ecosite. na $=$ missing sample.

Table 3. Ecosite cluster information.

\begin{tabular}{|c|c|c|c|}
\hline Ecosite cluster & Code & Ecosite classes & Number of sites \\
\hline Coniferous coarse & $\mathrm{CC}$ & $\mathrm{B} 052, \mathrm{~B} 067$ & 5 \\
\hline Deciduous coarse & $\mathrm{DC}$ & B055 & 3 \\
\hline Coniferous fine & $\mathrm{CF}$ & B098, B101, B116 & 8 \\
\hline Deciduous fine & DF & B104, B119 & 4 \\
\hline Organic & Org. & $\mathrm{B} 127, \mathrm{~B} 128, \mathrm{~B} 129$ & 6 \\
\hline
\end{tabular}




\section{Results and Discussion}

The main purpose of this study was to determine how key soil properties indicative of ecosystem function varied among different forest ecosite types at Hearst Forest. A comparison of the 14 properties measured for each mineral soil ecosite class (Table 2) gives the most direct insight into this question. Most properties were either quite similar between classes (e.g., bulk density, percent $\mathrm{OM}$ ) or extremely variable within each ecosite class (e.g., $\mathrm{NH}_{4}{ }^{+} \mathrm{N}, \mathrm{NO}_{3}{ }^{-} \mathrm{N}$, respiration). As a result, there were very few significant differences among the mineral soil ecosite types. Properties that did show significant differences were percent moisture, SOC, total N, and $\mathrm{C}: \mathrm{N}$ ratio (Table 2). Percent moisture was significantly higher in the $\mathrm{O}$ horizon of ecosite class B116 than in B055, B067, or B098. In the $0-10 \mathrm{~cm}$ increment, SOC and $\mathrm{N}$ both had significantly higher values in ecosite class B119 than in B052 or B067, while C:N ratio was significantly higher in ecosite class B116 than B052 or B104. Most properties generally showed depth trends that would be expected, such as decreasing percent moisture, increasing bulk density, decreasing SOC and total N, and decreasing C:N ratio with depth. Extractable $\mathrm{NH}_{4}{ }^{+}-\mathrm{N}$ and $\mathrm{NO}_{3}{ }^{-}-\mathrm{N}$ values were less consistent, but were generally highest in the $0-10 \mathrm{~cm}$ increment. Resin $\mathrm{NH}_{4}{ }^{+}-\mathrm{N}$ and $\mathrm{NO}_{3}{ }^{-}-\mathrm{N}$ had high $p$ values likely resulting from a combination of small sample sizes due to missing resin strips and high variability of values from remaining strips.

Organic ecosite classes (Table 4) showed the same general pattern of limited significant differences among ecosite types, with high within site variability (e.g., percent moisture, extractable- and resin-available $\mathrm{N}$, respiration). Although statistical comparisons between organic and mineral soil ecosite classes were not performed, organic classes appeared to have very different characteristics from mineral classes. Percent moisture, percent OM, SOC, total N, C:N ratio, respiration, net $\mathrm{N}_{\min }$, and WHC were all much higher in organic classes, while $\mathrm{pH}$ and extractable and resin available $\mathrm{NH}_{4}{ }^{+}-\mathrm{N}$ and $\mathrm{NO}_{3}{ }^{-}-\mathrm{N}$ appeared largely similar between the two general class types.

Table 4. Whole-profile organic ecosite property averages (standard errors).

\begin{tabular}{|c|c|c|c|c|}
\hline Property & $p$ value & B127 & B128 & B129 \\
\hline Moisture (\%) & 0.47 & $289.90(92.36)$ & $576.69(147.02)$ & $473.19(0.38)$ \\
\hline Bulk density $\left(\mathrm{g} / \mathrm{cm}^{3}\right)$ & 0.76 & $0.094(0.010)$ & $0.081(0.0095)$ & $0.090(0.0084)$ \\
\hline $\mathrm{pH}$ & 0.39 & $5.07(0.69)$ & $6.59(0.64)$ & $6.68(0.29)$ \\
\hline OM (\%) & 0.99 & $86.65(3.06)$ & $86.77(2.08)$ & $86.42(2.17)$ \\
\hline $\mathrm{SOC}(\mathrm{Mg} / \mathrm{ha})$ & 0.45 & $170.68(46.15)$ & $174.98(33.67)$ & $237.05(19.73)$ \\
\hline Total N (Mg/ha) & 0.62 & $4.85(0.88)$ & $4.93(0.65)$ & $6.40(1.03)$ \\
\hline $\mathrm{C}: \mathrm{N}$ ratio & 0.83 & $34.61(3.23)$ & $35.21(2.16)$ & $37.53(2.97)$ \\
\hline $\mathrm{NH}_{4}^{+}-\mathrm{N}(\mathrm{mg} / \mathrm{ha})$ & 0.46 & $1.93(0.90)$ & $1.97(0.29)$ & $8.57(1.15)$ \\
\hline $\mathrm{NO}_{3}^{-}-\mathrm{N}(\mathrm{mg} / \mathrm{ha})$ & 0.18 & $7.26(7.26)$ & $0.76(0.65)$ & $0.05(0.05)$ \\
\hline Respiration (ug C/g soil/min) & 0.81 & $76.35(34.52)$ & $104.66(30.61)$ & $127.35(62.87)$ \\
\hline Respiration (ug C/g soil C/min) & 0.32 & $177.91(95.9)$ & $211.36(66.46)$ & $255.27(129.27)$ \\
\hline Resin $\mathrm{NH}_{4}^{+}-\mathrm{N}$ (ug N/g resin) & 0.17 & $29.92(13.08)$ & $0.75(0.07)$ & $1.74(\mathrm{na})$ \\
\hline Resin $\mathrm{NO}_{3}{ }^{-}-\mathrm{N}$ (ug N/g resin) & 0.87 & $76.83(76.74)$ & $2.34(1.84)$ & $2.16(1.75)$ \\
\hline Net $\mathrm{N}_{\min }(\mathrm{mg} \mathrm{N} / \mathrm{kg}$ soil/day) & 0.98 & $20.74(3.23)$ & $35.21(2.16)$ & $37.53(2.97)$ \\
\hline $100 \% \mathrm{WHC}$ & 0.94 & $628.93(217.37)$ & $651.03(110.95)$ & $580.41(66.26)$ \\
\hline
\end{tabular}


Analysis of ecosite clusters (Table 5) revealed that increased within-group replication did not yield more differences between ecosite types. Only one property was found to have a statistically significant difference: O horizon bulk density was higher in the DC cluster than in the other three. Most properties still displayed high within-cluster variability, although some ANOVA $p$ values were approaching significance. If the results are interpreted with a $p$ value of 0.1 instead of 0.05 , there are significant differences in total N 0-10 cm $(p=0.055), 10-20 \mathrm{~cm}(p=0.076), 20-40 \mathrm{~cm}(p=0.063)$ and SOC $0-10 \mathrm{~cm}(p=0.086)$. For these factors, both the DC and DF clusters had higher values than the CF and CC. $\mathrm{C}: \mathrm{N}$ ratio was also significant in the $0-10 \mathrm{~cm}$ increment $(p=0.066)$, with $\mathrm{CF}$ having a larger ratio than the other three clusters.

For total ecosystem C comparisons (Table 6), the organic cluster held over two-fold more SOC than any mineral soil cluster. Within mineral soil clusters, the DF cluster had significantly higher SOC than the $\mathrm{CC}$ cluster. Although aboveground $\mathrm{C}$ did not differ between any clusters, total $\mathrm{C}$ was significantly higher in the organic cluster than the four mineral clusters by about a factor of two.

The fertility class (from Figure 1) comparisons (Table 7) showed no significant differences between the two classes for either extractable $\mathrm{N}$ and total $\mathrm{N}$ for any depth. Extractable $\mathrm{N}$ in the $10-20 \mathrm{~cm}$ increment was approaching significance $(p=0.056)$, with a higher value in the rich class.

Overall, our results show few statistically significant differences in measured properties between ecosite classes in the Hearst Forest. To assess the implications of this conclusion for the ecosite system, it is first useful to examine the differences that were found in terms of their relations to the ecological drivers used for classification. Among the mineral soil ecosites (Table 2), which represent the most diverse range of soil and vegetation conditions, only three properties were found to vary significantly between classes. The first was percent moisture, which was higher in the $\mathrm{O}$ horizon of B116 (moist, fine, spruce-fir conifer) than in B055 (dry to fresh, spruce-fir conifer), B067 (moist, coarse, spruce-fir conifer) and B098 (fresh, silty to fine loamy, black spruce jack pine dominated). The high percent moisture in B116 corresponds with its moist class description and is higher than the dry to fresh class B055 and the fresh class B098, as expected. However, classes B116 and B067 were both classified as moist but exhibited significantly different moisture levels. Although general textural differences between the fine textured B116 and the coarse B067 could be expected to explain moisture differences (e.g., [28]), this is unlikely to influence the $O$ horizon moisture values as texture in the classification system is based on mineral soil analysis. Furthermore, no moisture differences were found in any mineral soil depth increments between any classes. While moisture in the classification system is representative of a range of possible values, the difference between the two moist ecosite classes B067 and B116 may illustrate the importance of fine scale controls such as microtopography [29] that are difficult to capture through sampling procedures or adequately characterize for an entire ecosite polygon through commonly used remote sensing techniques. 
Table 5. Ecosite cluster property averages (standard errors) by depth.

\begin{tabular}{|c|c|c|c|c|c|c|}
\hline Property & Depth & $p$ value & $\mathbf{C C}$ & DC & $\mathbf{C F}$ & DF \\
\hline \multirow[t]{4}{*}{ Moisture (\%) } & O horiz & 0.26 & $116.46(28.13)$ & $71.20(12.17)$ & $156.65(33.67)$ & $141.62(36.01)$ \\
\hline & $0-10$ & 0.32 & $26.73(0.83)$ & $31.44(4.56)$ & $37.06(6.92)$ & $41.93(8.87)$ \\
\hline & $10-20$ & 0.3 & $19.29(0.96)$ & $22.17(3.01)$ & $20.40(1.44)$ & $23.65(1.00)$ \\
\hline & $20-40$ & 0.56 & $18.38(1.62)$ & $19.94(1.32)$ & $20.42(0.97)$ & $18.49(1.10)$ \\
\hline \multirow[t]{4}{*}{ Bulk density $\left(\mathrm{g} / \mathrm{cm}^{3}\right)$} & O horiz & 0.0066 & $0.21(0.063) \mathrm{a}$ & $0.70(0.21) \mathrm{b}$ & $0.19(0.027) \mathrm{a}$ & $0.24(0.036) \mathrm{a}$ \\
\hline & $0-10$ & 0.66 & $0.86(0.029)$ & $0.89(0.046)$ & $0.76(0.086)$ & $0.81(0.047)$ \\
\hline & $10-20$ & 0.71 & $1.23(0.026)$ & $1.11(0.052)$ & $1.26(0.092)$ & $1.27(0.11)$ \\
\hline & $20-40$ & 0.54 & $1.40(0.071)$ & $1.42(0.12)$ & $1.50(0.045)$ & $1.52(0.059)$ \\
\hline \multirow[t]{4}{*}{$\mathrm{pH}$} & O horiz & 0.41 & $6.01(0.38)$ & $6.79(0.15)$ & $6.22(0.22)$ & $6.13(0.32)$ \\
\hline & $0-10$ & 0.82 & $5.99(0.28)$ & $6.40(0.48)$ & $6.09(0.19)$ & $5.94(0.45)$ \\
\hline & $10-20$ & 0.12 & $5.63(0.35)$ & $5.26(0.21)$ & $6.17(0.15)$ & $6.06(0.33)$ \\
\hline & $20-40$ & 0.25 & $6.36(0.52)$ & $6.27(0.32)$ & $7.25(0.16)$ & $6.98(0.65)$ \\
\hline $\mathrm{OM}$ & O horiz & 0.4 & $72.52(8.22)$ & $53.17(6.28)$ & $62.78(6.64)$ & 70.88 (5.74) \\
\hline \multirow[t]{3}{*}{$(\%)$} & $0-10$ & 0.18 & $5.99(0.77)$ & $9.01(0.78)$ & $11.06(2.13)$ & $12.36(2.88)$ \\
\hline & $10-20$ & 0.12 & $3.01(0.35)$ & $4.64(0.44)$ & $3.96(0.51)$ & $5.24(0.95)$ \\
\hline & $20-40$ & 0.24 & $2.27(0.29)$ & $2.02(0.79)$ & $2.89(0.26)$ & $2.81(0.32)$ \\
\hline \multirow[t]{4}{*}{$\operatorname{SOC}(\mathrm{Mg} / \mathrm{ha})$} & O horiz & 0.54 & $12.98(5.33)$ & $2.96(0.62)$ & $13.45(5.38)$ & $4.78(1.29)$ \\
\hline & $0-10$ & 0.086 & $25.27(4.93)$ & 41.38 (1.73) & $37.76(4.22)$ & $49.94(10.71)$ \\
\hline & $10-20$ & 0.11 & $10.95(2.75)$ & $19.32(1.32)$ & $15.00(2.96)$ & 24.68 (5.56) \\
\hline & $20-40$ & 0.62 & $11.75(2.52)$ & $12.95(0.89)$ & $12.86(2.02)$ & 17.38 (4.92) \\
\hline \multirow[t]{4}{*}{ Total N (Mg/ha) } & O horiz & 0.61 & $0.44(0.19)$ & $0.067(0.017)$ & $0.45(0.21)$ & $0.14(0.063)$ \\
\hline & $0-10$ & 0.055 & $1.36(0.23)$ & $2.23(0.21)$ & $1.81(0.22)$ & $2.73(0.56)$ \\
\hline & $10-20$ & 0.076 & $0.90(0.21)$ & $1.42(0.19)$ & $1.19(0.15)$ & $1.67(0.21)$ \\
\hline & $20-40$ & 0.063 & $1.21(0.23)$ & $2.04(0.17)$ & $1.98(0.19)$ & $1.96(0.28)$ \\
\hline \multirow[t]{4}{*}{$\mathrm{C}: \mathrm{N}$ ratio } & O horiz & 0.68 & $55.25(23.56)$ & $45.14(2.27)$ & $35.83(3.51)$ & 41.67 (7.35) \\
\hline & $0-10$ & 0.066 & $18.29(0.95)$ & $18.74(1.23)$ & $21.30(0.94)$ & $18.19(0.21)$ \\
\hline & $10-20$ & 0.85 & $13.97(2.78)$ & $13.89(1.06)$ & $11.92(0.95)$ & $14.46(1.74)$ \\
\hline & $20-40$ & 0.14 & $10.12(1.95)$ & $6.46(0.89)$ & $6.42(0.69)$ & $8.51(1.33)$ \\
\hline \multirow[t]{3}{*}{$\mathrm{NH}_{4}{ }^{+}-\mathrm{N}(\mathrm{kg} / \mathrm{ha})$} & O horiz & 0.74 & $0.76(0.41)$ & $0.18(0.11)$ & $1.68(1.44)$ & $0.14(0.029)$ \\
\hline & $0-10$ & 0.83 & $2.54(1.20)$ & $3.96(2.91)$ & $2.38(0.87)$ & $0.95(0.14)$ \\
\hline & $10-20$ & 0.54 & $1.17(0.14)$ & $1.95(1.06)$ & $3.46(0.89)$ & $2.04(0.70)$ \\
\hline \multirow[t]{3}{*}{$\mathrm{NO}_{3}{ }^{-}-\mathrm{N}(\mathrm{kg} / \mathrm{ha})$} & O horiz & 0.73 & $0.035(0.035)$ & $0.0033(0.0033)$ & $0.051(0.051)$ & $0(0)$ \\
\hline & $0-10$ & 0.48 & $0.20(0.12)$ & $0.027(0.027)$ & $1.24(0.71)$ & $3.22(2.98)$ \\
\hline & $10-20$ & 0.24 & $0.072(0.056)$ & $0.05(0.05)$ & $0.38(0.16)$ & $0.97(0.57)$ \\
\hline Respiration (ug C/g soil/ min) & $0-10$ & 0.84 & $52.03(10.25)$ & $64.57(3.40)$ & $63.50(12.43)$ & $53.64(3.20)$ \\
\hline Respiration (ug C/g soil C/min) & $0-10$ & 0.18 & $1802.7(257.7)$ & $1386.3(33.76)$ & $1228.6(190.4)$ & $1041.2(304.6)$ \\
\hline Resin $\mathrm{NH}_{4}{ }^{+}-\mathrm{N}$ (ug N/g resin) & $0-10$ & 0.86 & $6.63(4.69)$ & $4.29(1.93)$ & $5.59(2.17)$ & $9.45(9.03)$ \\
\hline Resin $\mathrm{NO}_{3}-\mathrm{N}$ (ug N/g resin) & $0-10$ & 0.78 & $0.43(0.37)$ & $0.087(0.048)$ & $0.25(0.15)$ & $0.27(0.13)$ \\
\hline $\mathrm{Net}_{\mathrm{min}}(\mathrm{mg} \mathrm{N} / \mathrm{kg}$ soil/day) & $0-10$ & 0.25 & $4.11(0.80)$ & $0.73(0.58)$ & $4.25(1.15)$ & $3.75(0.98)$ \\
\hline $100 \% \mathrm{WHC}$ & $0-10$ & 0.27 & $64.60(5.51)$ & $81.23(4.34)$ & $84.22(10.76)$ & $97.60(13.38)$ \\
\hline
\end{tabular}

ANOVA $p$ values $<0.05$ are highlighted in bold; Significantly different values (Tukey's test $p<0.05$ ) are denoted by different letters row-wise per ecosite; CC denotes coniferous coarse, DC denotes deciduous coarse, $\mathrm{CF}$ denotes coniferous fine, DF denotes deciduous fine. 
Table 6. Ecosite cluster $\mathrm{C}$ analysis averages (standard errors). ANOVA $p$ values $<0.05$ are highlighted in bold.

\begin{tabular}{ccccccc}
\hline Property & $\boldsymbol{p}$ value & $\mathbf{C C}$ & DC & CF & DF & Organic \\
\hline SOC (Mg/ha) & $<\mathbf{0 . 0 1}$ & $61.0(8.3) \mathrm{a}$ & $76.6(3.4) \mathrm{ab}$ & $79.1(6.0) \mathrm{ab}$ & $96.8(13.1) \mathrm{b}$ & $194.2(20.7) \mathrm{c}$ \\
Aboveground C (Mg/ha) & 0.585 & $48.4(8.1)$ & $55.8(11.2)$ & $46.9(3.7)$ & $46.7(10.4)$ & $58.9(5.3)$ \\
Total C (Mg/ha) & $<\mathbf{0 . 0 1}$ & $109.4(7.3) \mathrm{a}$ & $132.4(14.3) \mathrm{a}$ & $126.0(3.9) \mathrm{a}$ & $143.5(20.6) \mathrm{a}$ & $253.1(23.0) \mathrm{b}$ \\
\hline
\end{tabular}

Significantly different values (Tukey's test $p<0.05$ ) are denoted by different letters row-wise per ecosite; SOC is calculated as total SOC to $40 \mathrm{~cm}$ depth, total $\mathrm{C}$ is calculated as the sum of SOC and aboveground C; CC denotes coniferous coarse, DC denotes deciduous coarse, CF denotes coniferous fine, DF denotes deciduous fine.

Table 7. Fertility class comparison averages (standard errors).

\begin{tabular}{ccccc}
\hline Property & Depth & P value & Poor & Rich \\
\hline Extractable N (kg/ha) & O horiz & 0.87 & $0.57(0.29)$ & $1.20(1.00)$ \\
& $0-10$ & 0.55 & $3.21(1.23)$ & $3.91(1.07)$ \\
& $10-20$ & 0.056 & $1.53(0.39)$ & $3.56(0.76)$ \\
Total N (Mg/ha) & O horiz & 0.62 & $301.75(136.34)$ & $349.74(142.17)$ \\
& $0-10$ & 0.22 & $1687.69(221.11)$ & $2117.12(256.47)$ \\
& $10-20$ & 0.23 & $1074.93(173.77)$ & $1353.15(136.50)$ \\
& $20-40$ & 0.10 & $1522.31(213.13)$ & $1973.84(148.02)$ \\
\hline
\end{tabular}

Differences were also found between ecosite classes for SOC, C:N ratio, and total N. These differences were only present in the upper $10 \mathrm{~cm}$ of mineral soil, which likely reflects the importance of litterfall and productivity as a control on forest soil biochemistry [30]. 0-10 cm SOC and total N were both highest in the B119 class (moist, fine, aspen-birch hardwood) and lowest in the B067 class (moist, coarse, spruce-fir conifer), while $\mathrm{C}: \mathrm{N}$ ratio was highest in class B116 (moist, fine, spruce-fir conifer). These patterns are consistent with the fact that coniferous species in the boreal forest are generally adapted to nutrient-poor conditions and occasionally seasonal waterlogging, requiring plant traits (e.g., higher nutrient use efficiency) that lead to low $\mathrm{C}$ input quantity and quality, while deciduous species often contribute greater amounts of high quality litter [31]. The patterns could also be related to textural differences, as SOC is generally higher for fine textured soils [32]. However, the lack of significant differences in these and other factors between other ecosites subject to contrasting ecological drivers suggests that these general controls do not consistently give rise to distinct by-ecosite characteristics in the Hearst Forest.

The generalized ecosite clusters (Tables 5 and 6) allow for a more straightforward examination of the relationships between soil texture, vegetation type, and $\mathrm{C}$ dynamics. Throughout the soil profile, the deciduous fine cluster had the highest SOC levels and the coniferous fine cluster had the lowest, although the differences were not significant when compared on a depth-by-depth basis (Table 5). When total SOC levels to $40 \mathrm{~cm}$ depth (Table 6) were compared, however, the difference between the two was significant $(p<0.01)$. Averaging the clusters further into simply coarse or fine classes shows that coarse clusters together contain an average of $68.8 \mathrm{Mg} / \mathrm{ha}$ of SOC to $40 \mathrm{~cm}$ depth, while the fine clusters have an average of $87.95 \mathrm{Mg} / \mathrm{ha}$. If the clusters are averaged by vegetation type, the coniferous sites contain $70.05 \mathrm{Mg} / \mathrm{ha}$ of SOC and the deciduous sites contain $86.70 \mathrm{Mg} / \mathrm{ha}$. This suggests that at 
this coarse level of aggregation, both vegetation type and soil texture may lead to distinct patterns in SOC consistent with general ecological understanding, with soil texture exerting a slightly stronger control.

Despite some differences at more generalized levels of classification, the fact that most biogeochemical properties tested in this study showed few or no significant differences at the ecosite level suggests that there are ecologically important factors that are not captured by the ecosite scale of classification. Soil properties vary temporally and spatially (both vertically in the soil profile and horizontally across an area), so most ecological studies rely on averages or generalizations to represent this variability. ELC itself is a method of attempting to account for soil and vegetation variability at many scales [1], and Ontario's ELC does include finer stratification levels used to inform ecosite classification (e.g., specific substrate types and soil horizon definitions) which should ideally average to yield distinct characteristics at the ecosite level sampled in this study. However, given the practical limitations related to sampling strategies in both the ecosite classification process and this study, it is difficult to characterize fine scale variability. For example, Simmons et al. [33] found in a study of bottomland forests that microtopography at scales of decimeters or less affected hydrologic conditions, nutrient concentrations, and species composition. Microbial communities, another important control on many soil processes, also vary substantially at fine scales; Snajdr et al. [34] assessed the spatial variability of enzyme activities and microbial biomass in upland hardwood forest soils and found significant differences between samples taken only $1 \mathrm{~cm}$ apart. Bengston et al. [35] integrated spatial relations between microbial processes, moisture, and plant-available nutrients, and found that while spatial autocorrelation at the scale of 100 s of meters was important for many factors, extractable $\mathrm{NH}_{4}{ }^{+}$ had a much shorter range of autocorrelation, likely related to spatially variable microbial processes.

Accounting for such variability is a common issue in soil sampling studies. While we took multiple soil cores to $40 \mathrm{~cm}$ depth in each plot, power analyses performed by Don et al. [36] determined the sample sizes required to show a 15\% difference in SOC stocks between treatments ranged from dozens to hundreds depending on soil horizon. Statistical power was shown to increase as horizons were grouped together, which supports the results shown for our whole-profile ecosite cluster comparisons (Table 6). Similarly, our $5.6 \mathrm{~cm}$ diameter soil cores may have been strongly affected by factors such as individual roots or macropores despite replication; greater generalization offered by other sampling methods such as soil pits may allow for better characterization of variability, particularly at scales relevant to trees. Overall, while the ecosite scale in Ontario's ELC is intended to account for heterogeneous ecological conditions within ecosite polygons and capture "recurring associations of vegetation type and substrate type combinations" [9], and ecosystem ecology generally considers ecosystem function as the aggregation of fine-scale processes, the combination of spatial variability and limited sampling time and resources in both ecosite classification and in this study may have contributed to the lack of statistically different patterns by ecosite class.

Temporal variability in forest properties during succession may also affect comparisons of soil properties among ecosite classes, as changes in species composition during succession may alter e.g., nutrient availability [37]. While the ecosite classification system is structured to account for vegetation growth stages (for example, each ecosite class has modifiers for general vegetation height), we did not have enough plots to select from to control for this within the ecosite class replicates. It is possible that past harvest activities or different successional stages at the sites we sampled affected the expected 
relationships between vegetation type and soil properties (particularly $\mathrm{C}$ and $\mathrm{N}$ dynamics). Forest harvest leads to the direct removal of $\mathrm{C}$ and $\mathrm{N}$ as biomass, as well as further $\mathrm{N}$ depletion related to changes in runoff, leaching rates, and biological functions [38]. $\mathrm{C}$ and $\mathrm{N}$ dynamics also change during forest recovery; Hynes and Germida [39] found differences in ammonia oxidizing bacteria and an overall decrease in inorganic $\mathrm{N}$ availability with time since harvest in central Alberta, and Nave et al. [40] found in a meta analysis of harvest impacts on $\mathrm{C}$ storage that $\mathrm{C}$ reductions and recovery rates depend on soil taxon and vegetation composition. These effects could disrupt expected steady-state $\mathrm{N}$ dynamics and $\mathrm{C}$ storage, contributing to the high variability within ecosite classes that we found.

Temporal variability over shorter time scales may also be important, as differences in moisture related to precipitation timing could influence the initial ecosite classification procedure as well as the determined moisture characteristics when we sampled. Although ecosites are generally not classified directly following precipitation events, both the measured percent moisture and WHC (a more stable, integrative measure of the potential for soil water retention) values in this study showed no differences in mineral soil increments by ecosite class. This indicates the ecosite classification system does not appear to be capturing variation in soil moisture regimes (which is explicitly identified for each ecosite class), suggesting the possible confounding influence of spatial or temporal variability in moisture levels.

In terms of fertility, our results demonstrate that the ecological drivers used in ecosite classification do not lead to distinct patterns in important processes such as nutrient and $\mathrm{C}$ cycling and microbial activity in mineral soil ecosites in the Hearst Forest. Fertility in the classification system is based on the fact that appropriate availability of nutrients and water on a site determines what vegetation will be found (i.e., vegetation types are implicitly associated with nutrient requirements). However, this does not appear to be reflected in the array of measures related to fertility that we used, such as one-time samples of extractable $\mathrm{N}$, three-month samples of resin-available $\mathrm{N}$, or laboratory-measured net $\mathrm{N}$ mineralization. The fertility class groupings (Table 7) confirm this variability-no significant differences between the two groups were found despite different fertility rankings according to the edatope grid (Figure 1). This lack of functional patterns for each ecosite class within the Hearst Forest suggests caution when using the ecosite classification system for operations requiring detailed biogeochemical understanding at scales applicable to forest management without a more explicit inclusion of finer scale ecological conditions. The same is true for the organic soil ecosites examined (Table 4), which showed no statistically significant differences despite their different fertility status according to the classification system.

At a more aggregated level, the split between organic and mineral soil ecosites appears to be meaningful; organic and mineral sites showed differences for most soil properties. The ecosite cluster $\mathrm{C}$ analysis (Table 6) illustrates the differences at this level of aggregation, with organic ecosites storing approximately twice as much total $\mathrm{C}$ than any mineral soil clusters. In terms of relative pool sizes, SOC accounted for an average of $61 \%$ of total $\mathrm{C}$ in mineral ecosites and $76 \%$ in organic ecosites. These findings support the use of the ecosite classification system as a way of estimating regional $\mathrm{C}$ stocks, but only at a coarse division between mineral and organic sites. It is possible that a more detailed sampling of a larger number of ecosites across distinct biogeoclimatic zones 
would reveal other ecosite class trends that could inform $\mathrm{C}$ inventories, but this dataset is limited to broader generalizations.

\section{Conclusions}

Ontario's boreal forest ecosite classification system represents an important tool that can be used to describe forest conditions at a level of detail applicable to many aspects of sustainable forest management. However, classification of sites based on the system's largely static ecological drivers and generalized vegetation conditions does not adequately capture many properties related to a range of biogeochemical processes at finer scales. The high spatial and temporal variability of ecological processes leads to high within-ecosite class variability and few distinct differences among the classes or aggregated clusters examined in this study. These results reflect the transience of biogeochemical properties and the difficulty of adequately grouping similar conditions at a scale relevant to detailed characterization of forest nutrient cycling and fertility.

\section{Acknowledgments}

We would like to thank George Graham of Thunderhouse Forest Services, Inc. and Hearst Forest Management Inc. (HFMI) for assistance with the resin strip collections at Hearst Forest and Doug Pitt (Canadian Wood Fibre Centre, Sault Ste. Marie, Canada) for contributions to the overall GEOIDE project at Hearst. Steve Koziar assisted with laboratory work to develop the methods for analyzing the resin strip extracts. Neal Scott acknowledges support from the Natural Sciences and Engineering Research Council. We would like to acknowledge the financial support of the GEOIDE Network Centre of Excellence through funding of the project entitled 'Precision Planning Inventory Tools for Forest Value Enhancement'. This, along with in-kind support of the Ontario Ministry of Natural Resources and Queen's University, is gratefully acknowledged. We also thank two anonymous reviewers, whose constructive comments greatly improved the paper.

\section{Conflicts of Interest}

The authors declare no conflict of interest.

\section{References}

1. Zenner, E.K.; Peck, J.L.E.; Brubaker, K.; Gamble, B.; Gilbert, C.; Heggenstaller, D.; Hickey, J.; Sitch, K.; Withington, R. Combining ecological classification systems and conservation filters could facilitate the integration of wildlife and forest management. J. For. 2010, 108, 296-300.

2. Rowe, J.S.; Sheard, J.W. Ecological land classification: A survey approach. Environ. Manag. 1981, 5, 451-464.

3. Klijn, F.; de Haes, H.A.U. A hierarchical approach to ecosystems and its implications for ecological land classification. Landsc. Ecol. 1994, 9, 89-104. 
4. Marshall, I.B.; Schut, P.H.; Ballard, M. A National Ecological Framework for Canada; Agriculture and Agri-Food Canada, Centre for Land and Biological Resources Research and Environment Canada: Ottawa, Canada, 1999.

5. Ontario Ministry of Natural Resources. Forest Resource Assessment Policy; Forest Management Branch: Sault Ste. Marie, ON, Canada, 2003.

6. Hills, G.A. The Classification and Evaluation of Site for Forestry; Research Report 24; Division of Research, Ontario Department of Lands and Forests: Toronto, Canada, 1952.

7. Hills, G.A. The use of site in forest management. For. Chron. 1953, 29, 128-136.

8. Ontario Ministry of Natural Resources. Ecological Land Classification Primer; Policy and Planning Coordination Branch: Toronto, Canada, 2007.

9. Banton, E.; Johnson, J.; Lee, H.; Racey, G.; Uhlig, P.; Wester, M. Ecosites of Ontario; Operational Draft; Ecological Land Classification Working Group, Ontario Ministry of Natural Resources: Sault Ste. Marie, ON, Canada, 2009.

10. Pokharel, B.; Dech, J.P. An ecological land classification approach to modeling the production of forest biomass. For. Chron. 2011, 87, 23-32.

11. Fielder, S.; Jungkunst, H.P.F.; Jahn, R.; Kleber, M.; Sommer, M.; Stahr, K. Linking soil classification and soil dynamics-Pedological and ecological perspectives. J. Plant Nutr. Soil Sci. 2002, 165, 517-529.

12. Sims, R.A.; Corns, I.G.W.; Klinka, K. Introduction-Global to local: Ecological land classification. Environ. Monit. Assess. 1996, 39, 1-10.

13. Binkley, D.; Giardina, C. Why do tree species affect soils? The warp and woof of tree-soil interactions. Biogeochemistry 1998, 42, 89-106.

14. Thomas, K.D.; Prescott, C.E. Nitrogen availability in forest floors of three tree species on the same site: The role of litter quality. Can. J. For. Res. 2000, 30, 1698-1706.

15. Scott, N.A.; Binkley, D. Foliage litter quality and annual net $\mathrm{N}$ mineralization: Comparison across North American forest sites. Oecologia 1997, 111, 151-159.

16. Gower, S.T.; Son, Y. Differences in soil and leaf litterfall nitrogen dynamics for five forest plantations. Soil Sci. Soc. Am. 1992, 56, 1959-1966.

17. Paré, D.; Bergeron, Y. Effect of colonizing tree species on soil nutrient availability in a clay soil of the boreal mixedwood. Can. For. Res. 1996, 26, 1022-1031.

18. Grayston, S.J.; Prescott, C.E. Microbial communities in forest floors under four tree species in coastal British Columbia. Soil Biol. Biogeochem. 2005, 37, 1157-1167.

19. Ekstrom, B. Forest Management Plan for the Hearst Forest; Hearst Forest Management, Inc.: Hearst, ON, Canada, 2007.

20. Lathja, K.; Jarrell, W.M.; Johnson, D.W.; Sollins, P. Collection of soil solution. In Standard Soil Methods for Long-Term Ecological Research; Robertson, G.P., Coleman, D.C., Bledsoe, C.S., Sollins, P., Eds.; Oxford University Press: New York, NY, USA, 1999; pp. 167-170.

21. Nelson, D.W.; Sommers, L.E. Total carbon, organic carbon, and organic matter. In Methods of Soil Analysis, Part III. Chemical Methods; Sparks, D.L, Ed.; Soil Science Society of America: Madison, WI, USA, 2009; pp. 961-1010.

22. Rayment, G.E.; Lyons, D.J. Total organic matter, organic C, and carbonate by loss on ignition. In Soil Chemical Methods: Australasia; Csiro Publishing: Collingwood, Australia, 2010; pp. 86-92. 
23. U.S. Environmental Protection Agency. Nitrogen, Ammonia. Method 350.1 (Colorimetric, Automated, Phenate). In Methods for Chemical Analysis of Water and Wastes; U.S. EPA: Cincinnati, OH, USA, 1983; pp. 350-1.1-350-1.4.

24. U.S. Environmental Protection Agency. Nitrogen, Nitrate-Nitrite. Method 353.2 (Colorimetric, Automated, Cadmium Reduction). In Methods for Chemical Analysis of Water and Wastes; U.S. EPA: Cincinnati, OH, USA, 1983; pp. 353-2.1-353-2.5.

25. Ter-Mikaelian, M.T.; Korzukhin, M.D. Biomass equations for sixty-five North American tree species. For. Ecol. Manag. 1997, 97, 1-24.

26. R Development Core Team. R: A Language and Environment for Statistical Computing; R Foundation for Statistical Computing: Vienna, Austria, 2011.

27. Jansen, V.M.; Chodak, M.; Saborowski, J.; Beese, E. Determination of humus stocks and qualities of forest floors in pure and mixed stands of spruce and beech. Allgemeine Forst Und Jagdzeitung 2005, 176, 176-186.

28. Cosby, B.J.; Hornberger, G.M.; Clapp, R.B.; Ginn, T.R. A statistical exploration of the relationships of soil moisture characteristics to the physical properties of soils. Water Res. Res. 1984, 20, 682-690.

29. Balisky, A.C.; Burton, P.J. Root-Zone soil temperature variation associated with microsite characteristics in high-elevation forest openings in the interior of British Columbia. Agri. For. Meteorol. 1995, 77, 31-54.

30. Flanagan, P.W.; Van Cleve, K. Nutrient cycling in relation to decomposition and organic matter quality in taiga ecosystems. Can. J. For. Res. 1983, 13, 795-817.

31. De Deyn, G.B.; Cornelissen, J.H.C.; Bardgett, R.D. Plant functional traits and soil carbon sequestration in contrasting biomes. Ecol. Lett. 2008, 11, 516-531.

32. Schimel, D.S.; Braswell, B.H.; Holland, E.A.; McKeown, R.; Ojima, D.S.; Painter, T.H.; Parton, W.J.; Townsend, A.R. Climatic, edaphic, and biotic controls over storage and turnover of carbon in soils. Glob. Biogeochem. Cycles 1994, 8, 279-293.

33. Simmons, M.E.; Wu, X.B.; Whisenant, S.G. Plant and soil responses to created microtopography and soil treatments in bottomland hardwood forest restoration. Restor. Ecol. 2011, 19, 136-146.

34. Snajdr, J.; Valaskova, V.; Merhautova, V.; Herinkova, J.; Cajthaml, T.; Baldrian, P. Spatial variability of enzyme activities and microbial biomass in the upper layers of Quercus petraea forest soil. Soil Biol. Biochem. 2008, 40, 2068-2075.

35. Bengston, P.; Basiliko, N.; Prescott, C.E.; Grayston, S.J. Spatial dependency of soil nutrient availability and microbial properties in a mixed forest of Tsuga heterophylla and Pseudotsuga menziesii in coastal British Columbia, Canada. Soil Biol. Biogeochem. 2007, 39, 2429-2435.

36. Don, A.; Barwolff, M.; Kalbitz, K.; Andruschkewitsch, R.; Jungkunst, H.F.; Schulze, E. No rapid soil carbon loss after a windthrow event in the High Tatra. For. Ecol. Manag. 2012, 276, 239-246.

37. Brais, S.; Camire, C.; Bergeron, Y.; Pare, D. Changes in nutrient availability and forest floor characteristics in relation to stand age and forest composition in the southern part of the boreal forest of northwestern Quebec. For. Ecol. Manag. 1995, 76, 181-189. 
38. Grigal, D.F. Effects of extensive forest management on soil productivity. For. Ecol. Manag. 2000, 138, 167-185.

39. Hynes, H.M.; Germida, J.J. Relationship between ammonia oxidizing bacteria and bioavailable nitrogen in harvested forest soils of central Alberta. Soil Biol. Biochem. 2012, 46, 18-25.

40. Nave, L.E.; Vance, E.D.; Swanston, C.W.; Curtis, P.S. Harvest impacts on soil carbon storage in temperate forests. For. Ecol. Manag. 2010, 259, 857-866.

(C) 2014 by the authors; licensee MDPI, Basel, Switzerland. This article is an open access article distributed under the terms and conditions of the Creative Commons Attribution license (http://creativecommons.org/licenses/by/3.0/). 